\title{
TRADISI APPAENRE NANRE DALAM PERSPEKTIF AQIDAH ISLAM (Studi Kasus Masyarakat Desa Bollangi Kecamatan Pattalassang)
}

\author{
Audah Mannan, Mantasia \\ e-mail: audahmannan@yahoo.co.id
}

\begin{abstract}
Abstrak
Pokok masalah penelitian ini adalah bagaimana Peran Muballigh Dalam Meminimalisir Tradisi Appaenre Nanre pada Masyarakat Desa Bollangi yang Bertolak Belakang dengan Aqidah Islam. Pokok masalah tersebut selanjutnya dibagi dalam beberapa sub masalah yaitu: 1) Bagaimana Tradisi Appaenre Nanre pada Masyarakat Desa Bollangi Kecamatan Pattallassang?, 2) Bagaimana Pandangan aqidah Islam terhadap Tradisi Appaenre Nanre pada Masyarakat desa Bollangi Kecamatan Pattallassang?

Jenis penelitian ini tergolong kualitatif dengan pendekatan penelitian yang digunakan adalah: pendekatan manajemen dakwah dan sosiologi Islam. Adapun sumber data penelitian ini adalah tokoh masyarakat, tokoh agama, tokoh adat, tokoh pemuda dan pemerintah setempat. Selanjutnya, metode pengumpulan data yang digunakan adalah observasi, wawancara, dan dokumentasi.

Hasil penelitian ini menggambarkan tentang potret tradisi Appaenre Nanre pada Masyarakat Desa Bollangi Kecamatan Pattallassang, suatu tradisi yang telah melekat dalam kehidupan masyarakat namun pelaksanaan tradisi Appaenre Nanre bergeser dari ajaran Islam sehingga masyarakat perlu diberikan suatu pemahaman yang lebih dalam mengenal aqidah Islam dan dalam hal ini muballigh sebagai tokoh Agama memiliki peranan yang sangat penting dalam memberikan pemahaman dan pencerahan terhadap masyarakat Desa Bollangi.
\end{abstract}

Keywords:

Tradisi ,Appaenre, Nanre, Aqidah, Islam

\section{PENDAHULUAN}

\section{A. Latar Belakang Masalah}

Setiap bangsa tentunya memiliki Agama sebagai kepercayaan yang mempengaruhi manusia sebagai individu, juga sebagai pegangan hidup. Di samping Agama, kehidupan manusia juga dipengaruhi oleh kebudayaan. Kebudayaan menjadi identitas dari bangsa dan suku bangsa. Suku tersebut memelihara dan melestarikan budaya yang ada ${ }^{1}$.

Seiring kemajuan teknologi modern dan kecanggihannya terus berkembang, misalnya teknologi komunikasi memungkinkan manusia dapat berhubungan satu sama lain secara intens menyebabkan suatu informasi menyebar seluas-luasnya tanpa mengenal batas-batas wilayah. Mereka bersentuhan dengan nilai yang mungkin berbeda

${ }^{1}$ Bustanidum Agus, Islam dan Pembangunan (Jakarta: PT Raja Grafindo Persada, 2002), h. 15 
dengan apa yang dianutnya selama ini. Sistem nilai budaya yang dipilih secara selektif oleh individu atau kelompok dalam suatu masyarakat akan menjadi pandangan hidup bagi individu atau kelompok dalam suatu masyarakat tersebut.

Tradisi adalah kebiasaan yang turun temurun dalam suatu masyarakat. Dalam pengertian yang paling sederhana adalah sesuatu yang telah dilakukan sejak lama dan menjadi bagian dari kehidupan suatu kelompok masyarakat. Tradisi merupakan mekanisme yang dapat membantu untuk memperlancar perkembangan pribadi anggota masyarakat, misalnya dalam membimbing anak menuju kedewasaan. Jika tradisi mulai bersifat absolute, nilainya sebagai pembimbing akan merosot. Jika tradisi mulai absolute bukan lagi sebagai pembimbing, melainkan merupakan penghalang kemajuan.Oleh karena itu, tradisi yang kita terima perlu kita renungkan kembali dan kita sesuaikan dengan zamannya. ${ }^{2}$

Tradisi merupakan keyakinan yang dikenal dengan istilah animisme dan dinamisme. Animisme berarti percaya kepada roh-roh halus atau roh-roh leluhur yang ritualnya terekspresikan dalam persembahan tertentu di tempat-tempat yang keramat. Kepercayaan seperti itu adalah Agama mereka yang pertama, semua yang bergerak dianggap hidup dan mempunyai kekuatan gaib atau memiliki roh yang berwatak buruk maupun baik. Dengan kepercayaan tersebut mereka beranggapan bahwa di samping semua roh yang ada,terdapat roh yang paling berkuasa dan lebih kuat dari manusia. Dan, agar terhindar dari roh tersebut mereka menyembahnya dengan jalan upacara yang disertai dengan sesaji-sesaji. ${ }^{4}$

Dinamisme adalah suatu istilah dalam antropologi untuk menyebut sesuatu pengertian tentang sesuatu kepercayaan. Meyakini bahwa benda-benda tertentu memiliki kekuatan gaib, karena itu harus dihormati dan terkadang harus dilakukan ritual tertentu untuk menjaga tuah-nya. Melalui proses pewarisan, dari generasi ke generasi lain, tradisi mengalami perubahan-perubahan baik dalam skala besar maupun kecil. Oleh karena itu, dalam memandang hubungan Islam dengan tradisi atau kebudayaan selalu terdapat variasi interpretasi sesuai dengan konteks lokalitas masingmasing. ${ }^{5}$ Meskipun muslim di Indonesia mengakui sumber universal yang sama yaitu Al-Qur'an dan As-Sunnah, tapi interpretasi atas ajaran dan praktek-praktek keagamaan sangat beragam.

Budaya merupakan suatu cara hidup yang berkembang dan dimiliki bersama oleh sebuah kelompok orang dan diwariskan dari generasi ke generasi berikutnya dan terdapat nilai-nilai atau konsep-konsep yang tumbuh dan dipelihara berdasarkan sosio-kulturalnya. Budaya dapat dianggap sebagai identitas suatu bangsa, terutama Indonesia yang kaya akan sumber daya alamnya juga kaya pula akan budayanya.

\footnotetext{
${ }^{2}$ Mardimin Johanes, Jangan Tangisi Tradisi (Yogyakarta: Kanisius, 1994), h. 12-13.

${ }^{3}$ Kuncoriningrat, Sejarah Kebudayaan Indonesia (Yogyakarta: Jambatan, 1954), h. 103

${ }^{4}$ Darori Amin, Islam dan Kebudayaan Jawa (Yogyakarta: Gama Media, 2000), h. 6

${ }^{5}$ Ahmad Khalil, Islam Jawa Sufisme dalam Etika dan Tradisi Jawa (Uin-Malang Press, 2008), h. 1-3.
} 
Meskipun ditemukan kemiripan antara suatu budaya dengan kebudayaan yang lain, dikarenakan adanya percampuran budaya (akulturasi) secara perlahan. Dalam suatu kebudayaan terdapat rangkaian adat-istiadat serta tradisi. Hal tersebut saling berkaitan satu dengan yang lainnya.Tradisi dapat dikatakan sebagai suatu kebiasaan yang tentunya kerap dilakukan hingga membentuk suatu pola adat-istiadat yang dilakukan masyarakat dan terus dipertahankan. Dan adat istiadat tersebut telah disepakati oleh masyarakat sehingga membudaya dalam kehidupan bermasyarakat.

Masyarakat di Desa Bollangi, keseluruhan adalah beragama Islam, mereka memiliki sebuah tradisi yang sudah ada sejak lama di desa itu yakni Tradisi Appaenre Nanre, tradisi ini adalah tradisi yang turun temurun dari nenek moyang di masyarakat desa Bollangi, tradisi ini dilakukan oleh sebagian besar warga bahkan orang-orang yang berada di luar pemukiman itupun seringkali berkunjung ke puncak gunung tersebut yang sering mereka sebut dengan "Appaenre Nanre". Tradisi tersebut dilakukan saat seseorang atau sekelompok orang berniat untuk berkunjung ke puncak gunung tersebut. Selain niat, adapula warga yang berkunjung ke puncak gunung tersebut karena adanya janji atau nazar yang telah diucapkan. Misalnya seseorang bernazar jika anaknya lulus di suatu pekerjaan ia akan naik ke puncak gunung tersebut.

Warga yang melakukan ritual ke puncak gunung yang mereka sebut dengan karaeng itu, harus membawa sesajian, songkolo, ayam dan lain sebagainya, serta yang tidak boleh dilupakan adalah Dupa. Dupa adalah suatu benda yang di dalamnya terdapat asap yang dijadikan warga setempat untuk melaksanakan ritual tersebut.

Tradisi tersebut dilakukan pada hari senin dan kamis, selain kedua hari itu, warga setempat tidak diperbolehkan untuk berkunjung ke tempat tersebut. Seseorang yang tidak memiliki niat atau nazar untuk berkunjung ke puncak gunung tersebut tidak diperbolehkan untuk lewat ataupun datang langsung ke tempat tersebut. Setiap warga yang memiliki janji untuk berkunjung ke puncak gunung tersebut, kemudian ia tidak menepatinya maka dipercayai warga setempat, orang tersebut akan mendapat celaka,bahkan ada warga sampai meninggal dunia.

Dalam melakukan tradisi ini, ada seseorang yang memimpin adat itu, yang mereka sebut dengan sanro atau pinati. Sanro atau pinati tersebutlah yang mengatur segala bentuk yang dibutuhkan dalam proses ritual tersebut. Sehubungan dengan itu, Islam adalah Agama risalah yang dibawa oleh Nabi Muhammad saw. Kepada umatnya dan para pengikutnya untuk memahami dan menghayati masyarakat tentang nilai-nilai ajaran Agama Islam, karena itu Agama Islam adalah tagyir atau perubahan dapat terlaksana akibat pemahaman dan penghayatan nilai-nilai ajaran Islam yang bersumber dari Al-Qur'an dan Sunnah. Dengan demikian dimaksud perubahan masyarakat Islam yang menurut arah yang diinginkan. ${ }^{6}$ Agama menyediakan perangkat nilai, norma dan aturan yang meliputi segenap aspek hidup manusia, tidak terkecuali dalam hidup bermasyarakat. Dengan bimbingan Agama diharapkan manusia mendapatkan pegangan yang pasti dan benar dalam menjalani hidup dan membangun peradabannya

${ }^{6}$ Zainuddin, M.Z., Figur Da’i Berjuta Umat (Cet, I. Surabaya : Penerbit Kurnia, 1995), h. 185 


\section{B. Rumusan Masalah}

Berdasarkan latar belakang masalah yang dikembangkan, maka dapat dikemukakan pokok masalahnya yaitu "Bagaimana Peran Muballigh dalam Meminimalisir Tradisi Appaenre Nanre pada Masyarakat Desa Bollangi Kecamatan Pattallassang".

1. Bagaimana Tradisi Appaenre Nanre pada Masyarakat Desa Bollangi Kecamatan Pattallassang?

2. Bagaimana Peran Muballigh dalam Meminimalisir Tradisi Appaenre Nanre pada Masyarakat Desa Bollangi Kecamatan Pattallassang yang Bertolak Belakang dengan Aqidah Islam?

\section{Tujuan dan Kegunaan Peneliti}

Tujuan yang ingin dicapai dalam peneliti ini adalah

1. Untuk mengetahui Tradisi Appaenre Nanre pada Masyarakat Desa Bollangi Kecamatan Pattallassang.

2. Untuk mengetahui Peran Muballigh dalam Meminimalisir Tradisi Appaenre Nanre pada Masyarakat Desa Bollangi Kecamatan Pattallassang yang bertolak belakang dengan aqidah Islam.

\section{TINJAUAN TEORETIS}

\section{A. Tradisi dalam Pandangan Islam}

\section{Pengertian Tradisi Islam}

Tradisi berasal dari kata "traditium" pada dasarnya berarti segala sesuatu yang berupa diwarisi dari masa lalu.Tradisi merupakan suatu kebiasaan yang berkembang dimasyarakat baik yang menjadi adat kebiasaan, atau yang diasimilasikan dengan ritual adat atau Agama. Tradisi merupakan hasil cipta dan karya manusia, objek material, kepercayaan, khayalan, kejadian, atau lembaga yang diwariskan dari sesuatu generasi ke generasi berikutnya. $^{7}$

Tradisi merupakan sebuah persoalan dan yang lebih penting lagi adalah bagaimana tradisi tersebut terbentuk. Tradisi terkadang disamakan dengan kata-kata adat yang dalam pandangan masyarakat awam dipahami sebagai struktur yang sama. Dalam hal ini sebenarnya berasal dari bahasa arab adat (bentuk jamak dari "adah") yang berarti kebiasaan dan dianggap bersinonim dengan "urf, sesuatu yang dikenal atau diterima secara umum.

Kata 'urf berasal dari kata 'arafa, ya'rifu sering diartikan dengan "al-ma'ruf" dengan arti "sesuatu yang dikenal". Pengertian "dikenal" ini lebih dekat dengan pengertian "diakui oleh orang lain". Sesuatu yang baru dilakukan satu kali, belum dinamakan adat. Tentang berapa kali satu perbuatan harus dilakukan untuk sampai

\footnotetext{
${ }^{7}$ Tradisi”, M. Wikipedia. http://id. M. Wikipedia. Org/wiki/tradisi (02 Desember 2013).
} 
disebut adat, tidak ada ukurannya dan banyak tergantung pada bentuk perbuatan yang dilakukan tersebut.

Urf pengertiannya tidak melihat dari segi berulang kalinya suatu perbuatan dilakukan, tetapi dari segi bahwa perbuatan tersebut sudah sama-sama dikenal dan diakui oleh orang banyak. ${ }^{8}$ Kata 'urf dan adat yaitu suatu pebuatan yang telah berulang-ulang dilakukan menjadi dikenal dan diakui orang banyak, sebaliknya karena perbuatan itu dilakukan orang secara berulang kali. Dengan demikian meskipun dua kata tersebut dapat dibedakan tetapi perbedaannya tidak berarti. Tradisi Islam merupakan hasil dari proses dinamika perkembangan Agama tersebut dalam ikut serta mengatur pemeluknya dalam melakukan kehidupan sehari-hari. Tradisi Islam lebih mengarah pada peraturan yang sangat ringan terhadap pemeluknya dan selalu tidak memaksa terhadap ketidakmampuan pemeluknya.

Seperti halnya adat-istiadat, kesenian dan properti yang digunakan. Sesuatu yang diwariskan tidak berarti harus diterima, dihargai, atau disimpan sampai mati. Bagi para pewaris setiap mereka di warisi tidak dilihat sebagai "tradisi". Tradisi yang diterima akan menjadi unsur yang hidup di dalam kehidupan para pendukungnya. Ia menjadi bagian dari masa lalu yang dipertahankan sampai sekarang dan mempunyai kedudukan yang sama dengan inovasi-inovasi baru. ${ }^{9}$

Harapandi Dahri, mendefinisikan tradisi sebagai suatu kebiasaan yang teraplikasikan secara terus-menerus dengan berbagai simbol dan aturan yang berlaku pada sebuah komunitas. Awal mula dari sebuah tradisi adalah ritual- ritual individu kemudian disepakati oleh beberapa kalangan dan akhirnya diaplikasikan secara bersama-sama dan bahkan tak jarang tradisi-tradisi itu berakhir menjadi sebuah ajaran yang jika ditinggalkan akan mendatangkan bahaya ${ }^{10}$.

Pendapat lain dikemukakan oleh Imam Hanafi tradisi adalah lahir dan dipengaruhi oleh masyarakat, kemudian masyarakat muncul dan dipengaruhi oleh tradisi. Tradisi pada mulanya merupakan musabab, namun akhirnya menjadi konklusi dan permis, isi dan bentuk, efek dan aksi pengaruh dan mempengaruhi ${ }^{11}$.

Tradisi merupakan suatu gambaran sikap dan perilaku manusia yang telah berproses dalam waktu lama dan dilakukan secara turun-temurun dimulai dari nenek moyang. Tradisi yang telah membudaya akan menjadi sumber dalam berakhlak dan berbudi pekerti seseorang. Tradisi atau kebiasaan, dalam pengertian yang paling sederhana adalah sesuatu yang telah dilakukan sejak lama dan menjadi bagian dari kehidupan suatu kelompok masyarakat, biasanya dari suatu Negara, kebudayaan, waktu, atau Agama yang sama. Hal yang paling mendasar dari tradisi adalah adanya informasi yang diteruskan dari generasi ke generasi baik tertulis maupun lisan, karena tanpa adanya ini, suatu tradisi dapat punah. Selain itu tradisi juga dapat diartikan sebagai

${ }^{8}$ Amir Syarifuddin, Ushul Fiqih (Jakarta: Kencana, 2011), h. 387

${ }^{9}$ Agus Ahmad Safei, Dasar-Dasar Tradisi (Jakarta: Bumi Aksara, 1993), h. 139-140.

${ }^{10}$ Harapendi Dahri, Jejak Cinta Keluarga Nabi Di Bengkulu (Jakarta: Penerbit Cinta, 2009), h. 45.

\footnotetext{
${ }^{11}$ Hasan Hanafi, Oposisi Pasca Tradisi (Yogyakarta: Sarikat, 2003), h. 2
} 
kebiasaan bersama dalam masyarakat manusia, yang secara otomatis akan mempengaruhi aksi dan reaksi dalam kehidupan sehari-hari para anggota masyarakat itu. $^{12}$ Tradisi yang harus dipertahankan adalah tradisi yang tidak bergeser dari ajaran Islam.

\section{Dasar Hukum Tradisi}

Hukum adalah menciptakan sesuatu atas sesuatu atau yang meniadakannya. ${ }^{13}$ Islam adalah Agama yang diwahyukan Allah swt. Kepada Nabi Muhammad saw. Sebagai Rasul dan untuk disampaikan kepada manusia. Mereka yang terbiasa dengan pekerjaan berbuat syirik kepada Allah dengan menyediakan piduduk, diancam oleh Allah berupa ancaman tidak akan diberikan ampunan, sebagaimana dengan melakukan perbuatan dosa lainnya selain syirik. Kepada mereka akhlus syrik yang meskipun tanpa sadar telah melakukan kesyirikan karena kejahilannya terhadap ilmu Agama, maka tidak ada cara lain yang harus dipilih dan ditempuh kecuali melakukan taubat meminta ampun atas perilaku sesat yang telah dilakukan, karena taubat dapat menghapus segala dosa.

\section{Macam-Macam Adat}

Penggolongan macam-macam adat atau 'urf dapat dilihat dari beberapa segi: ${ }^{14}$

a. Ditinjau dari segi materi yang biasa dilakukan. Dari segi ini 'urf itu ada dua macam:

1) 'urf qauli yaitu kebiasaan yang berlaku dalam penggunaan kata-kata atau ucapan.

2) 'urffi'li yaitu kebiasaan yang berlaku dalam perbuatan.

b.Dari segi ruang lingkup penggunaannya, 'urf terbagi:

1) Adat atau 'urf umum, yaitu kebiasaan yang telah umum berlaku dimanamana, tanpa memandang Negara, bangsa, dan Agama.

2) Adat atau 'urf khusus, yaitu kebiasaan yang dilakukan sekelompok orang di tempat tertentu atau pada waktu tertentu, tidak berlaku disemua tempat dan disembarang waktu.

c. Dari segi penilaian baik dan buruk, adat atau 'urf itu terbagi atas:

1) Adat yang shahih, yaitu adat yang berulang-ulang dilakukan, diterima oleh orang banyak, tidak bertentangan dengan Agama, sopan santun, dan budaya yang luhur. Contohnya mengadakan acara halalbihalal (silaturahmi) saat hari raya.

2) Adat yang fasid, yaitu adat yang berlaku di suatu tempat meskipun merata pelaksanaannya, namun bertentangan dengan Agama, undang-undang Negara dan sopan santun. Contohnya berjudi untuk merayakan suatu

\footnotetext{
${ }^{12}$ Sidi Gazalba, Asas-Tradisi, Kebudayaan (Jakarta: Bulan Bintang, 1978), h. 308.

${ }^{13}$ Nasrun Haroen MA, Ushul Fiqh (Jakarta: PT. Logos Wacana Ilmu, 2001), h. 207

${ }^{14}$ Amir Syarifuddin, Ushul Fiqih, h. 389
} 
peristiwa. $^{15}$ Adat jenis ini tidak diharuskan untuk memeliharanya karena memeliharanya itu berarti menentang dalil syara'.

\section{Adat dalam Hukum Islam}

Islam datang dengan seperangkat norma syara' yang mengatur kehidupan muamalah yang harus dipatuhi umat Islam sebagai konsokuensi dari keimanannya kepada Allah dan Rasul-Nya. Sebagian dari adat lama itu ada yang selaras dan ada yang bertentangan dengan hukum syara' yang datang kemudian. Adat yang bertentangan itu dengan sendirinya tidak mungkin dilaksanakan oleh umat Islam secara bersamaan dengan hukum syara'. Pertemuan antara adat dan syari'at tersebut terjadilah perbenturan, penyerapan dan pembauran antara keduanya. Dalam hal ini yang diutamakan adalah proses penyeleksian adat yang dipandang masih diperlukan untuk dilaksanakan. Adapun yang dijadikan pedoman dalam menyeleksi adat untuk dilaksanakan. Adapun yang dijadikan pedoman dalam menyeleksi adat lama itu adalah kemaslahatan menurut wahyu.

Berdasarkan hasil seleksi tersebut, adat dapat dibagi kepada 4 kelompok sebagai berikut:

a. Adat yang lama secara substansial dan dalam hal pelaksanaannya mengandung unsur kemaslahatan. Adat dalam bentuk ini diterima sepenuhnya dalam hukum Islam.

b. Adat lama yang pada prinsipnya secara substansial mengandung unsur maslahat (tidak mengandung unsur mudarat), namun dalam pelaksaanaannya tidak dianggap baik oleh Islam.

c. Adat lama yang pada prinsip dan pelaksaanaannya mengandung unsur mafsadat (merusak). Maksudnya yang dikandungnya hanya unsur perusak dan tidak memiliki unsur manfaat.

d. Adat atau 'urf yang telah berlangsung lama, diterima oleh orang banyak karena tidak mengandung unsur perusak dan tidak bertentangan dengan dalil syara $^{16}$ yang datang kemudian, namun secara jelas belum terserap ke dalam syara', baik secara langsung atau tidak langsung.

\section{Tradisi Appaenre Nanre}

Tradisi Appaenre Nanre adalah salah satu tradisi yang sudah sejak lama ada di Desa Bollangi Kecamatan Pattallassang, masyarakat setempat melakukan ritual tersebut saat memiliki nazar untuk naik ke puncak gunung yang mereka sebut dengan Karaeng Bollangi. Setidaknya permasalahan umat Islam dapat dibagi dalam dua kategori. Kategori ini dirumuskan setelah melihat permasalahan yang ada yaitu problema aqidah dan problema akhlak.

\section{a. Problema Aqidah}

\footnotetext{
${ }^{15}$ Amir Syarifuddin, Ushul Fiqih, h. 390-392.

${ }^{16}$ Amir Syarifuddin, Ushul Fiqih, h. 394.
} 
Pembangunan yang dicanangkan adalah bukan hanya pembangunan ekonomi, dan sosial kemasyarakatan saja tetapi juga menyangkut pembangunan rohani dalam artian pembangunan manusia seutuhnya. Hal ini perlu disadari mengingat pembangunan yang selama ini dirasakan lebih banyak memperhatikan aspek fisik jasmani dibandingkan dengan pembangunan pada bidang rohani (mental spiritual). Akibatnya kemajuan dibidang pembangunan fisik terasa begitu cepat, munculnya gedung-gedung bertingkat, pusat-pusat perbelanjaan tumbuh dengan pesat, jalan-jalan baru dibangun, dan berbagai fasilitas lainnya tersedia dimana-mana.

Situasi seperti itu terjadi karena terdapat kesalahan paradigma dalam melihat kemajuan suatu bangsa atau masyarakat. Kemajuan sesuatu seringkali diindikasikan dengan kemajuan fisik seperti, banyaknya gedung bertingkat, alat transportasi yang lengkap, sarana komunikasi modern dan sebagainya. ${ }^{17}$ Masih jarang terdengar bahwa kemajuan suatu bangsa atau masyarakat berdasarkan pada kurangnya tindakan kriminal, norma-norma agama dan masyarakat berjalan dengan baik serta berbagai aspek moralitas lainnya. Keduanya mengandung kelemahan yang sangat mendasar, yaitu semakin menjauh dari aspek moralitas dan ajaran Agama. Pembangunan fisik telah mencapai kemajuan yang sangat pesat tetapi berbagai persoalan umat yang sangat mendasar masih sering terjadi seperti persoalan aqidah (keyakinan), persoalan akhlak seperti kenakalan remaja, dan berbagai persoalan sosial kemasyarakatan lainnya.

Syirik adalah menduakan atau menyamakan Allah dengan yang lainnya. Syirik secara umum dapat dikatakan sebagai kecondongan untuk bersandar pada sesuatu atau pun seseorang selain Allah. Hal ini akan terjadi pada orang-orang yang tidak mampu mengendalikan nafsu jahatnya, karena sesungguhnya nafsu jahat itu, lebih suka menyembah produk imajinasinya sendiri. Fenomena seperti itu juga sudah merasuki masyarakat muslim di dunia. Sebagaimana Allah berfirman dalam QS. An- Nisa/4:48.

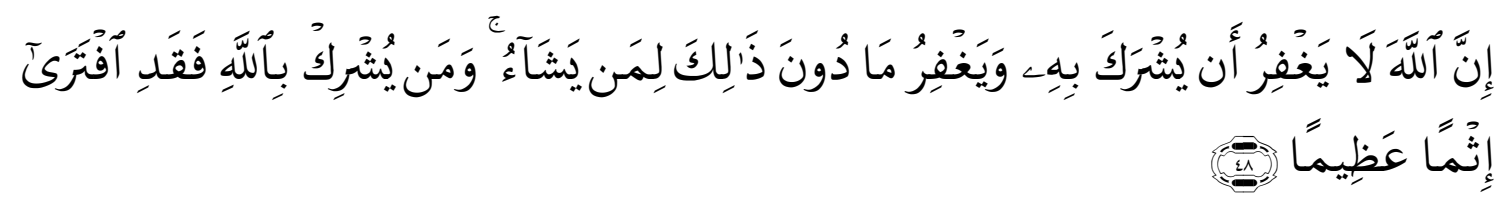

Terjemahnya:

Sesungguhnya Allah tidak akan mengampuni dosa syirik, dan Dia mengampuni segala dosa yang selain dari (syirik) itu, bagi siapa yang dikehendaki-Nya. Barangsiapa yang mempersekutukan Allah, Maka sungguh ia telah berbuat dosa yang besar. ${ }^{18}$

Ayat di atas menjelaskan bahwa dosa syirik adalah dosa yang tidak akan diampuni oleh Allah swt. Karena syirik adalah dosa yang sangat besar. Seringkali tanpa disadari manusia telah mempertuhankan sesuatu selain dari Allah. Sebagai contoh dalam kehidupan sehari-hari terdapat umat Islam yang tidak memperdulikan lagi

\footnotetext{
${ }^{17}$ Nurhidayat Muhammad Said, Dakwah dan Efek Globalisasi Informasi (Makassar: Alauddin University Press, 2011), h. 91

${ }^{18}$ Departemen Agama RI, Al-Qur'an dan Terjemahnya (Jakarta : Intermasa, 1993), h.87
} 
shalat hanya karena memburu materi. Uang telah menjadi "Tuhan baru" dalam mengisi aktivitas kehidupannya, sehingga kebutuhan spiritual dilupakan. Terdapat beberapa kategori syirik. Pertama Syirk al-ilm yaitu syirik yang umumnya terjadi di kalangan ilmuwan. Mereka mengagungkan ilmu sebagai satu-satunya kekuatan atau menjadi sombong karena ilmu yang dimilki. Sehingga tidak mempercayai lagi pengetahuan yang diwahyukan oleh Allah swt.

Fenomena globalisasi infomasi juga telah "menciptakan" manusia yang Syirk alilm. Dengan kepintaran yang dimiliki membuatnya sombong dan angkuh sehingga menafikkan keberadaan Allah sebagai zat yang maha luas ilmunya. Kedua Syirk altasarruf yaitu syirik jenis ini pada prinsipnya disadari atau tidak oleh pelakunya, menentang bahwa Allah Maha Kuasa dan segala kendali atas kehidupan manusia. Berada di tangan-Nya. Mereka percaya adanya perantara bagi Allah dan percaya pula bahwa sang perantara itu mempunyai kekuasaan yang sama dengan Allah ${ }^{19}$.Syirik jenis ini justru banyak menghinggapi orang-orang yang masih memiliki tingkat pengetahuan yang rendah.

\section{b. Problema Akhlak}

Manusia harus mengatur dimensi-dimensi wujudnya dalam berbagai arah sedemikian rupa sehingga memungkinkan dia memenuhi semua tuntutan dan kebutuhan material dan spiritualnya dan hidup secara pantas dengan mendasarkan kehidupannya pada suatu rencana yang disusun dengan tepat dan akurat. Manusia harus membangun suatu masyarakat yang tertib bebas dari konflik, agresi, kejahilan dan dosa.

Penyebab melemahnya keutuhan umat Islam karena semakin lemahnya umat Islam dalam berinteraksi dengan ajaran Islam yang dianutnya. Dan yang lebih memprihatinkan lagi terdapat umat Islam yang tidak memahami Islam itu sendiri, Islam hanya dipandang sebagai ritual ibadah, identik dengan masjid, pengajian dan sebagainya.

\section{METODOLOGI PENELITIAN}

\section{A. Jenis Penelitian dan Lokasi Penelitian}

Penelitian ini menggunakan metode deskriptif yang menggunakan pendekatan kualitatif. Yang bertujuan untuk mendeskripsikan. Tradisi Appaenre Nanre pada Masyarakat Desa Bollangi Kecamatan Pattallassang. Lokasi penelitian ini di Desa Bollangi Kecamatan Pattallassang Kabupaten Gowa.

\section{B. Pendekatan Penelitian}

Metode pendekatan yang digunakan dalam penelitian ini adalah pendekatan komunikasi dan sosiologi Islam yaitu secara langsung mendapat informasi dari informan untuk mendapatkan data dan informasi mengenai Tradisi Appaenre

\footnotetext{
${ }^{19}$ Nurhidayat Muhammad Said, Dakwah dan Efek Globalisasi Informasi, h. 92-94
} 
Nanre pada Masyarakat Desa Bollangi Kecamatan Pattallassang (Pendekatan Manajemen Dakwah).

\section{Sumber Data}

\section{Sumber Data Primer}

Data empirik diperoleh secara langsung dengan melaksanakan wawancara terhadap beberapa informan yang berhubungan langsung dengan seseorang yang mengerti dan di percayai untuk mengurus segala proses pelaksanaan tradisi Appaenre Nanre pada masyarakat Desa Bollangi Kecamatan Pattallassang. Tokoh adat dan Tokoh Agama, yaitu seorang da'i yang mengerti tentang hukum-hukum Agama Islam.

\section{Sumber Data sekunder}

Data sekunder adalah data yang diperoleh lewat pihak lain, tidak langsungdiperoleh peneliti dari subjek penelitiannya, biasanya berwujud dokumentasi. Data sekunder biasa juga berarti data yang berasal dari bahan kepustakaan.

\section{Metode Pengumpulan Data}
1. Metode Observasi
2. Metode Wawancara
3. Metode Dokumentasi

\section{E. Instrumen Penelitian}

Salah satu faktor penunjang keberhasilan dalam sebuah penelitian adalah instrumen atau alat yang digunakan dalam pengumpulan data dibutuhkan beberapa nstrument sebagai alat untuk mendapatkan data yang dibutuhkan dalam sebuah penelitian.

Dalam penelitian ini penulis menggunakan beberapa instrument sebagai penunjang dalam penelitian yaitu mencatat hasil observasi dan wawancara, pedoman wawancara dan telaah kepustakaan seperti kamera handphone, perekam suara handphone, pulpen dan buku catatan.

\section{F. Teknik Analisis Data}

1. Reduksi data adalah proses pemulihan, perumasan penelitian perhatian pada penyederhanaan, pengabstrakan dan transformasi data-data yang ada pada data yang relevan atau sesuai dengan permasalahan penelitian.

2. Penyajian data yaitu penyusunan data-data yang telah diperoleh dengan mengambarkan fenomena atau keadaan sesuai dengan data yang telah direduksi secara sederhana sehingga mudah dipahami biasanya dalam bentuk test naratif.

3. Kesimpulan yaitu: dengan menyimpulkan permasakahan yang menjadi pokok penelitian dalam rumusan masalah, sehingga dapat ditarik sesuatu kesimpulan untuk penyelesaian permasalahan yang didapati dari penyajian $\mathrm{n}$ yang ada atau catatan-catatan yang tersimpan dan lain sebagainya. 


\section{HASIL DAN PEMBAHASAN}

\section{A. Tradisi Appaenre Nanre pada Masyarakat Desa Bollangi Kecamatan Pattallassang}

\section{Sejarah Tradisi Appaenre Nanre}

Awal mula munculnya tradisi Appaenre Nanre dimulai dengan datangnya seorang pemuda, usianya masih sekitar 20 tahun, ia datang ke desa Bollangi kemudian mewarisi tradisi Appaenre Nanre hingga saat ini. Seperti yang dikatakan salah satu tokoh adat bahwa:

Dahulu kala ada seorang pemuda yang berasal dari Bone, pemuda itu sakit selama tiga bulan, tubuhnya kesakitan. Ia seperti didatangi oleh sebuah ruh yang memperlihatkan bahwa ada sebuah tempat sakral yang harus dia datangi dan membawa makanan sebagai persembahannya. Kemudian beberapa tahun kemudian, tempat keramat tersebut pindah ke Desa Bollangi dan secara temurun diwarisi dari generasi ke generasi. ${ }^{20}$

Tradisi ini sudah ada sejak lama, tak jelas tahun berapa, namun banyak orang yang beranggapan bahwa tradisi ini sudah ada sejak berabad-abad. Tradisi Appaenre Nanre adalah suatu tradisi yang telah lama dilakukan oleh masyarakat desa Bollangi dan diwariskan dari generasi ke generasi.

\section{Tradisi Appaenre Nanre}

Tradisi Appaenre Nanre adalah tradisi yang dilakukan oleh masyarakat Desa Bollangi dan dilakukan secara turun temurun, masyarakat melakukan tradisi ini ketika Masyarakat desa Bollangi mayoritas beragama Islam, namun sebagian dari mereka masih percaya dengan ruh-ruh yang menurut mereka bisa mendapatkan kebahagiaan dan kesuksesan. Tradisi tersebut dilakukan pada hari senin dan kamis, selain kedua hari itu, warga setempat tidak diperbolehkan untuk melaksanakan tradisi Appaenre Nanre, tak ada alasan yang jelas mengapa pelaksanaan tradisi tersebut harus dilakukan pada hari senin dan kamis, mereka hanya mempercayai bahwa kedua hari tersebut adalah hari yang paling baik. Adapula warga yang hanya berniat untuk melakukan tradisi Appaenre Nanre tanpa adanya nazar. Seseorang yang tidak memiliki niat atau nazar untuk berkunjung ke gunung tersebut tidak diperbolehkan untuk lewat ataupun datang langsung ke tempat tersebut.

\section{Proses Pelaksanaan}

Proses pelaksanaan tradisi Appaenre Nanre terbagi atas tiga yaitu:

1) Pelaksanaannya dilakukan di puncak gunung yang mereka sebut dengan Karaeng

\footnotetext{
${ }^{20}$ Dg Pa’ja (80 tahun), Tokoh Adat. “Wawancara”, Pattallassang, 1 Juni 2017
} 
2) Proses pelaksanaan tradisi dilakukan di rumah salah satu tokoh adat yang disebut pinati.

Banyak orang yang tidak bisa langsung membawa makanannya ke gunung Karaeng Bollangi karena jaraknya terlalu jauh, sehingga mereka dapat melakukan proses ritual kesalah satu rumah tokoh adat. Jika ada masyarakat yang ingin melakukan "Appaenre Nanre" mereka bisa datang kesini, di rumah ini sudah ada tempat yang dibuat yang disamakan dengan yang ada di gunung karaeng Bollangi. ${ }^{21}$ Tempat yang dimaksud adalah sebuah tempat yang dikhususkan yang berada di dalam kamar. Tempat itu berisi tempat tidur dan juga rumah-rumah kecil. Dan adapun makanan yang disajikan dalam pelaksanaan tradisi Appaenre Nanre adalah sebagai berikut: a) Songkolo b) Telur c) Ayam d) Ikan

Ayam yang disiapkan adalah sebanyak dua ekor, ada dua hidangan yang harus disiapkan pada saat proses ritual. Namun dalam pelaksanaan tradisi Appaenre Nanre adapula yang hanya menyajikan ikan, tergantung dari niat masyarakat, dan proses ritualnya pun tidak harus seperti pada saat penyembelihan seekor sapi yang harus terlihat sakral. Kemudian, selain makanan adapula alatalat yang harus dipersiapkan dalam proses pelaksaan tradisi Apaenre Nanre yaitu diantaranya:

1. Kipas 2. Ju'ju 3. Gong 4. Alawida 5. Tepa-tepa 6. Lilin 7. Bendera

8. Sapu lidi 9. Daun sirih 10. Gendang 11. Pui-pui

Gendang adalah salah satu perlengkapan yang tidak boleh dilupakan pada saat proses ritual penyembelihan seekor sapi. Semua alat-alat tersebut digunakan saat proses pelaksaan tradisi Appaenre Nanre, kemudian diletakkan berdampingan dengan makanan yang telah disajikan, dan pada saat tradisi berlangsung pinati membacakan sebuah bacaan yang sudah turun temurun menjadi bacaannya, namun bacaan itu tidak boleh diketahui oleh siapapun. Pada saat yang bersamaan alat-alat tersebut di bawa seperti sedang menggendong bayi kemudian berjalan mengelilingi makanan yang telah disajikan. Terkecuali gendang dan pui-pui kedua alat ini digunakan saat proses penyembelihan seekor sapi. Semua alat-alat ini digunakan pada saat proses ritual dilaksanakan di atas gunung, sedangkan jika hanya di rumah salah satu tokoh adat maka, alat-alat tersebut tidak harus digunakan. ${ }^{22}$

3) Pelaksanaan tradisi Appaenre Nanre dilakukan di salah satu tempat di desa Bollangi yang disebut dengan Batu Mallipung Batu Mallipung adalah tempat dimana masyarakat melakukan tradisi Appaenre Nanre, masyarakat mengatakan bahwa zaman dahulu nenek moyang mereka sering melihat ada seseorang yang sedang menenun di tempat itu. Sejak saat itu secara turun temurun sebagian dari masyarakat melakukan tradisi Appaenre Nanre di tempat

\footnotetext{
${ }^{21}$ Dg Pa'ja (80 tahun), Tokoh Adat, “Wawancara”, Pattallassang 1 Juni 2017

${ }^{22} \mathrm{Dg}$ Ngasih (75 tahun), Tokoh Adat, “Wawancara”, Pattallassang, 1 Juni 2017.
} 
itu. Ada berbagai macam hal yang melatarbelakangi warga melaksanakan tradisi Appaenre Nanre diantaranya yaitu:

a. Bernazar.

b. Hanya sekedar berniat

c. Adapula yang datang setelah acara pernikahan.

d. Ada yang datang ke gunung Karaeng Bollangi tersebut sebelum acara pernikahan dengan bermalam dan membawa seekor sapi kemudian disembelih di atas gunung tersebut. Penyembelihan seekor sapi harus dibarengi dengan tepukan gendang oleh seorang laki-laki, berbeda dengan hanya membawa seekor kambing atau ayam tidak perlu membawa gendang.

e. Pakaian

Proses pelaksanaan tradisi Appaenre Nanre pakaian yang dipakai tidak boleh sembarangan, tokoh adat atau pinati harus memakai baju lengan pendek ketika melakukan tradisi tersebut di atas gunung yang mereka sebut dengan Karaeng Bollangi. Akan tetapi saat melakukan tradisi bukan di atas puncak gunung atau di rumah salah satu tokoh adat, maka pakaian yang dikenakan tidak diharuskan memakai baju lengan pendek. ${ }^{23}$ Pakaian yang digunakan dalam pelaksanaan tradisi tidak harus selalu memakai baju lengan pendek.

\section{B. Peran Muballigh dalam Meminimalisir Tradisi Apaaenre Nanre yang Bertolak Belakang dengan Aqidah Islam}

Muballigh merupakan salah satu unsur dakwah yang sangat menentukan keberhasilan dakwah. Tidak semua muballigh sukses dan efektif di dalam dakwah. Sebaiknya yang terpilih dari mereka adalah orang-orang yang ahli dalam dakwah, luwes, fasih, dan cerdas.

Aktivitas dakwah pada awalnya hanyalah merupakan tugas sederhana yakni kewajiban untuk menyampaikan apa yang diterima dari Rasulullah saw. Sejalan dengan perputaran masa dan pergantian waktu, perkembangan masyarakat yang semakin meningkat, tuntutan yang semakin beragam, membuat dakwah dituntut untuk dilakukan secara modern. Untuk itu diperlukan sekelompok orang yang secara terus-menerus mengkaji, meneliti dan meningkatkan aktivitas dakwah secara professional. $^{24}$

Dakwah adalah usaha perubahan ke arah yang lebih baik dari situasi sebelumnya. Dakwah sangat erat kaitannya dengan perbaikan, pembaruan,dan pengembangan termasuk perbaikan pemahaman, cara berpikir dan bersikap.

Salah satu saran yang diberikan kepada $d a^{\prime} i$ adalah menggunakan dakwah rabbani. dakwah yang bersifat rabbani ini adalah dakwah yang pernah dilakukan oleh kaum generasi pertama Islam yang telah melepaskan manusia saat itu, dari terkaman

\footnotetext{
${ }^{23}$ Dg Pa'ja (80 tahun), Tokoh Adat, “Wawancara”, Pattallassang 1 Juni 2017.

${ }^{24}$ M. Yunan Yusuf, Metode Dakwah Sebuah Pengantar Kajian Dalam Munzier Suparta Dan Harjani Hefni, Metode Dakwah (Cet 2; Jakarta: Kencana. 2006), h. viii.
} 
dan perangkap sistem hidup jahiliyyah. Kemudian memuliakan manusia dengan hidayah iman dan Islam. ${ }^{25}$

Di desa Bollangi masyarakat telah lama melaksanakan tradisi Appaenre Nanre, tradisi tersebut sudah mendarahdaging di dalam kehidupan mereka. Para muballigh memiliki peran yang sangat penting dalam meminimalisir tradisi Appaenre Nanre yang sudah bertolak belakang dengan ajaran Islam. Muballigh dianggap sebagai seorang juru dakwah yang menyampaikan pencerahan kepada masyarakat. Kondisi masyarakat desa Bollangi yang sepertinya lebih takut dengan ruh-ruh itu dibanding dengan Tuhan yang menciptakannya dan tradisi yang dilakukan tersebut sudah termasuk syirik karena telah menduakan Tuhan.

Para tokoh Agama harus sering melakukan dakwah kepada masyarakat dan memberikan pemahaman kepada mereka bahwa tradisi itu tidak diajarkan dalam $\mathrm{Al}$ qur'an dan hadis karena tujuannya salah. Maka dari itu untuk menyampaikan sebuah ceramah muballigh harus memperhatikan metode dakwah yang perlu digunakan, Perhatian terhadap metode dakwah menjadi perhatian khusus bagi setiap da'i. Materi yang bagus tanpa dukungan terhadap metode yang benar kemungkinan besar akan mengalami kegagalan.

\section{Metode Dakwah}

Penggunaan metode yang benar merupakan unsur yang sangat penting dalam menunjang proses berhasilnya suatu kegiatan dakwah. Suatu pesan betapapun baiknya, tetapi disampaikan lewat metode yang tidak benar, pesan tersebut bisa jadi ditolak oleh masyarakat. Pada dasarnya metode dakwah tetap mengacu pada metode dakwah yang tertuang dalam QS.An Nahl/16:125.

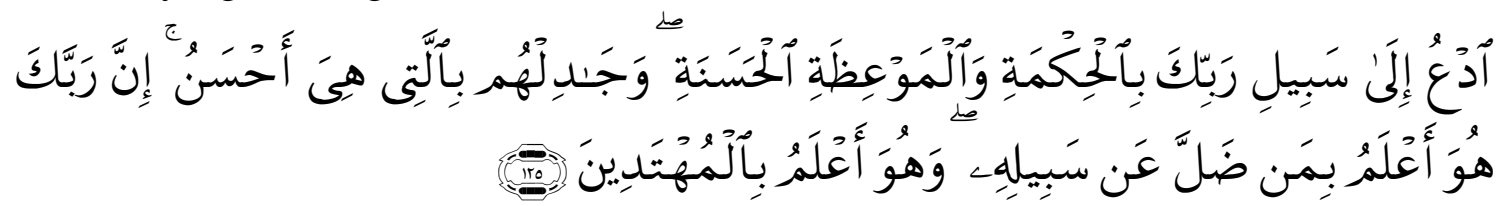

Terjemahnya:

Dialah yang lebih mengetahui tentang siapa yang tersesat dari jalan-Nya dan Dialah yang lebih mengetahui orang-orang yang mendapat petunjuk. Ayat di atas menjelaskan bahwa ada tiga metode yang dapat digunakan dalam menyampaikan dakwah yaitu bi al hikmah, al mau'izatil hasanah, dan wa jadilhum bi al-lati hiya ahsan.

\section{a. Metode bi al-hikmah}

Hikmah ialah perkataan yang tegas dan benar yang dapat membedakan antara yang hak dengan yang bathil. Al hikmah adalah ajakan atau seruan kepada jalan Allah dengan pertimbangan ilmu pengetahuan seperti bijaksana, adil, sabar dan penuh ketabahan serta selalu memperhatikan keadaan mad'u. Jadi dalam menyampaikan dakwah haruslah dengan penuh kesabaran dalam menghadapi masyarakat. Oleh karena itu, ada berbagai cara yang dapat dilakukan dalam metode al hikmah diantaranya:

\footnotetext{
${ }^{25}$ Nurhidayat Muhammad Said, Dakwah dan Efek Globalisasi Informasi, h. 116.
} 


\section{b. Metode al Mau'izatil hasanah}

Metode dakwah yang kedua yaitu memberikan nasehat yang baik, Metode al Mau'izatil hasanah, ada beberapa pengertian dalam metode ini diantaranya:

1) Pelajaran dan nasehat yang baik, gaya bahasa, teladan dan pencegahan dengan cara yang lembut.

2) Peringatan dengan menggunakan gaya bahasa yang mengesankan atau menyentuh hati.

3) Nasehat, bimbingan dan arahan untuk kemaslahatan dilakukan dengan baik dan penuh tanggung jawab, akrab, komunikatif, dan terkesan di hati masyarakat. Senantiasa melakukan percakapan dengan masyarakat seputar Agama.

4) Ucapan yang penuh kelembutan, tidak mengejek, melecehkan, menyudutkan atau menyalahkan.

\section{c. Metode wa jadilhum bi al lati hiya ahsan}

Metode wa jadilhum bi al lati hiya ahsan yaitu berakwah dengan jalan berbantahan, diskusi, berdebat dengan argumentasi yang kuat. Tetapi semua hal tersebut dilandasi dengan cara yang baik, saling menghormati antara satu dengan lainnya, antara kelompok yang satu dengan kelompok lainnya dengan etika dan tata karma.

Penyampaian dakwah harus mampu menjaga emosi agar lawan dialog merasa dirinya dihormati meskipun argumentasinya itu keliru. Bagi seorang da'i sudah harus menyadari bahwa tujuan dialog bukanlah memenangkan perdebatan, bukan mencari siapa yang benar dan siapa yang salah melainkan memberikan kepuasan kepada lawan dialog dan mencapai kebenaran untuk memperoleh jalan keluar dari setiap persoalan.

Metode wa jadilhum bi al lati hiya ahsan dalam pengaplikasiaannya dimasyarakat dapat dibagi ke dalam dua bentuk:

\section{1) Tanya jawab}

Metode ini dapat dijadikan pedoman dalam melakukan aktivitas dakwah. Seorang muballigh harus arif dan bijaksana dalam melihat setiap perkembangan yang terjadi dalam masyarakat. Metode pertanyaan ini dapat diberikan kepada masyarakat yang ingin bertanya, fungsi sorang muballigh disini adalah dengan menjawab pertanyaan-pertanyaan dari masyarakat secara jelas, tidak bertele-tele, yang penting dalam sebuah jawaban adalah inti dari pertanyaan, tidak perlu panjang lebar untuk menjelaskan yang penting jawaban yang diberikan sesuai dengan apa yang diinginka masyarakat, jawaban yang dapat menjawab persoalan masyarakat dann jawaban itu harus benar-benar meyakinkan yang bersumber dari Al qur'an. Dengan demikian yang mendengarnya akan terpuaskan hatinya dan siap menerima setiap yang disampaikan kepadanya. 


\section{2) Dialog (diskusi)}

Pada dasarnya tidak semua orang dapat menerima dakwah Islam secara langsung dalam arti mendengar dan taat terhadap yang didengarkan. Terkadang manusia perlu untuk mempertanyakan kebenaran materi dakwah yang disampaikan kepadanya. Diskusi merupakan salah satu pendekatan dakwah yang persuasif dan perlu adanya keahlian dari para da'i.

\section{Materi Dakwah}

Pada dasarnya materi dakwah kembali pada apa tujuan dakwah, karena pada dasarnya apa yang terdapat dalam materi dakwah bergantung pada tujuan dakwah yang ingin dicapai. Adapun materi dakwah yang perlu disampaikan pada masyarakat Desa Bollangi yaitu:

Syirik adalah menjadikan sesuatu tandingan bagi Allah, yang meyakini bahwa selain Allah ada yang mencipta, memberi rezki, menghidupkan, mematikan, mengetahui perkara gaib, mempercayai dukun atau paranormal, berdo'a, bernazar dan berharap selain kepada Allah.

Masyarakat desa Bollangi dalam melakukan ritual appaenre nanre disebabkan oleh kurangnya pengetahuan mereka dari ilmu Agama dan pendidikan yang rendah, sehingga mereka melakukan perbuatan kesyirikan yang mereka anggap hal merupakan yang dilakukan dan ketidaktahuan mereka dan tidak sadar bahwa syirik dapat menghapuskan segala amalan mereka. ${ }^{26}$

Syirik kepada Allah merupakan dosa terbesar, siapa menyembah selain kepada Allah berarti dia telah meletakkan ibadah di tempat yang salah. Syirik dapat menggugurkan semua amal perbuatan dan memastikan kebinasaan dan kerugian.

Ada beberapa hal yang harus disampaikan kepada masyarakat desa Bollangi mengenai syirik bahwa syirik dapat menjauhkan manusia dari Allah swt. Dan syirik adalah dosa yang sangat besar disisi Allah, dan tidak diampuni di hari kiamat, jika pelakunya tidak bertaubat sebelum ajal tiba serta diharamkan surga bagi pelaku kesyirikan.

Masyarakat desa Bollangi harus diberikan pemahaman bahwa iman kepada Allah merupakan pokok dari keimanan, yakni keyakinan yang pasti bahwa Allah adalah Rabb dan pemilik segala sesuatu, Dialah satu-satunya pencipta, pengatur segala sesuatu, Maha pemberi rezki, Maha segalanya dan Dialah satu-satunya yang berhak disembah, tidak ada sekutu bagi-Nya. Semua sesembahan selain Dia adalah sesembahan yang batil dan beribadah kepada selain-Nya adalah kebathilan. ${ }^{27}$

Materi dakwah yang disampaikan diharapkan dapat meluruskan aqidah dan pemahaman Agama masyarakat desa Bollangi yang selama ini telah percaya selain Juni 2017.

${ }^{26}$ Ardiansyah (28 tahun), Tokoh Agama Pa'baeng-Baeng, "Wawancara”, Pattallassang, 8

${ }^{27}$ Ardiansyah (28 tahun), Tokoh Agama Pa'baeng-Baeng, “Wawancara”, Pattallassang, 8 Juni 2017. 
kepada Allah, sehingga dapat kembali ke jalan yang diridahi oleh Allah swt. Peran seorang muballigh menjadi sangat penting di dalam memberikan pencerahan kepada umat manusia, khususnya masyarakat desa Bollangi yang memang jarang diadakan sebuah kegiatan atau pembinaan, maka dari itu dalam hal ini, perlu dilaksanakan suatu kegiatan dakwah yang dapat dihadiri oleh masyarakat dan menambah ilmu pengetahuan mereka mengenai ajaran Islam.

Penyampaian ajaran Islam kepada masyarakat tentunya harus dengan konsep yang matang, sebelum terjun kepada masyarakat, tentunya materi yang akan disampaikan harus disiapkan dengan perencanaan yang matang, karena persoalan yang terjadi dalam masyarakat desa Bollangi adalah mengenai akidah dan tauhid, maka materi yang harus pertama kali disampaikan adalah tentang akidah, tentang betapa Maha Besarnya Allah yang telah menciptakan alam semesta ini, dan masyarakat harus diyakinkan bahwa yang mereka percayai sebagai pemberi kebahagiaan bagi mereka, itu juga adalah ciptaan dari Tuhan.

Penyebab dari kurangnya pemahaman masyarakat mengenai Agama Islam juga disebabkan karena rendahnya tingkat pendidikan, sehingga diharapkan dengan adanya kajian yang diadakan di desa Bollangi dapat memberikan dan menambah ilmu pengetahuan mereka dan mereka juga dapat bertanya secara langsung kepada muballigh. Seperti contohnya, setiap kegiatan kajian masyarakat yang hadir dikegiatan tersebut ditantang menyiapkan sebuah pertanyaan pada pertemuan selanjutnya, dan dari pertanyaan itu akan diberikan pembahasan secara mendalam dan secara jelas.

Sebagai seorang tokoh Agama saya juga memiliki beberapa peranan yang lain diantaranya:

a. Sebagai educator, yaitu harus memiliki kemampuan untuk mendidik dan membimbing masyarakat supaya dapat memahami Agama Islam dengan kaffah dan mampu mengamalkan ajaran Agama dengan istiqomah yang diharapkan dapat mengubah kualitas seseorang dari segenggam pasir menjadi segenggam emas, artinya dapat mengubah manusia dari situasi yang tidak baik kepada situasi yang lebih baik.

b. Sebagai motivator, yaitu dengan memotivasi masyarakat secara langsung dengan bertemu agar mampu menjalankan nilai ajaran dengan sepenuh hati, sehingga masyarakat memiliki semangat untuk beragama dengan sempurna.

c. Sebagai konselor, yang dapat membimbing masyarakat untuk menyelesaikan problematika kehidupan pribadi, keluarga dan masyarakat. Yaitu dengan memberikan penyuluhan kepada masyarakat mengenai ajaran tauhid.

d. Sebagai inspirator, mampu menjadi inspirasi bagi masyarakat. Artinya, Segala ucapan, tindakan, kebiasaan dan karakternya akan selalu ditunggu dan dinilai oleh masyarakat, sehingga harus memiliki kemampuan untuk memberikan teladan yang baik kepada masyarakat. Apa yang kita katakan seharusnya sama dengan apa yang kita lakukan. Jangan jadikan nasihat- 
nasihat yang kita sampaikan itu sebagai pemicu dan motivasi agar kita segera dapat menjadi contoh yang baik. ${ }^{28}$

Muballigh memiliki peran yang sangat penting dalam mengajak manusia ke jalan Allah dengan senantiasa membimbing, mendidik, memberikan penyuluhan serta menjadi teladan yang baik bagi masyarakat sehingga masyarakat paham mengenai Agama Islam yang sesungguhnya dan memahami bahwa tiada Tuhan yang pantas disembah kecuali Allah swt.

\section{KESIMPULAN}

Berdasarkan hasil penelitian ini,maka penulis menyimpulkan bahwa:

1. Tradisi Appaenre Nanre adalah tradisi yang dilakukan oleh masyarakat desa Bollangi secara turun temurun, mereka masih percaya dengan ruh-ruh yang menurut mereka bisa mendapatkan kesejahteraan dan kesuksesan. Tradisi tersebut dilakukan pada hari senin dan kamis. Adapun proses pelaksaanaannya yaitu dilakukan di puncak gunung yang mereka sebut dengan Karaeng Bollangi dan proses pelaksanaan tradisi juga dapat dilakukan di rumah salah satu tokoh adat yang disebut pinati. Makanan yang disajikan dalam pelaksanaan tradisi Appaenre Nanre adalah Songkolo, Telur, Ayam, ikan. Adapula alatalat yang harus dipersiapkan dalam proses pelaksanaan tradisi Apaenre Nanre yaitu diantaranya kipas, ju'ju, gong, alawida, lilin, sapu lidi, tepa-tepa, bendera, daun sirih, gendang dan pui-pui.Yang melatarbelakangi warga melaksanakan tradisi Appaenre Nanre diantaranya yaitu bernazar, hanya sekedar berniat, Adapula yang datang setelah acara pernikahan dan ada yang datang ke gunung Karaeng Bollangi tersebut sebelum acara pernikahan dengan bermalam dan membawa seekor sapi kemudian disembelih 7di atas gunung tersebut. Dalam proses pelaksanaan tradisi Appaenre Nanre pakaian yang dipakai tidak boleh sembarangan, tokoh adat atau pinati harus memakai baju lengan pendek ketika melakukan tradisi tersebut. Sehingga dapat disimpulkan bahwa tradisi Appaenre Nanre termasuk tradisi yang mengandung nilai syirik, karena telah percaya selain kepada Allah swt.

2. Ada beberapa hal yang dapat dilakukan muballigh dalam meminimalisir tradisi Appaenre Nanre yang bertolak belakang dengan ajaran Islam diantaranya dengan berdakwah pada masyarakat dengan menyiapkan materi, maupun metode, dengan perencanaan yang matang. Kemudian dilakukan kagiatan jum'at ibadah dan pengajian rutin setiap minggu serta diadakannya kegiatan kajian Islami pada masyarakat desa Bollangi. Selain itu muballigh juga memiliki beberapa peranan yang lain diantaranya Sebagai educator, motivator, konselor dan inspirator.

${ }^{28}$ Rusli (30 tahun), Tokoh Agama Pa’baeng-Baeng, "Wawancara”, Pattallassang, 9 Juni 2017. 


\section{DAFTAR PUSTAKA}

Al-qur'anul Karim.

Arifuddin, Acep. Pengembangan Metode Dakwah. Cet I; Jakarta: Rajawali, 1998.

Abda, Slamet Muhaimin. Prinsip-Prinsip Metodologi Dakwah. Surabaya: Usaha Asaha Nasional, 1994.

Amin, Samsul Munir. Ilmu Dakwah. Jakarta: Amzah, 2009.

Agus , Bustanidum,. Islam dan Pembangunan. Jakarta: PT Raja Grafindo Persada, 2002.

Amin , Darori. Islam dan Kebudayaan Jawa. Yogyakarta: Gama Media, 2000.

Azhar, Arsyad. Media Pembelajaran. Jakarta: PT. Raja Frafindo Persada, 2006.

Aliyudin dan Enjang AS. Dasar-Dasar Ilmu Dakwah. Bandung: Widya Padjadjaran, 2009.

Bungin, Burhan. Penelitian Kualitatif. Cet I; Jakarta: Kencana, 2007.

Departemen Agama RI. Al Qur'an dan Terjemahnya. Jakarta: Intermasa, 1993.

Dahri , Harapendi. Jejak Cinta Keluarga Nabi di Bengkulu. Jakarta: Penerbit Cinta, 2009.

Helmy, Masdar. Dakwah dalam Alam Pembangunan. Semarang: CV Toha Putra,

Hadi, Sutrisno. Metodologi Research. Yogyakarta: UGM Press, 1999.

Hanafi, Hasan. Oposisi Pasca Tradisi. Yogyakart: Sarikat, 2003.

Johanes, Mardimin. Jangan Tangisi Tradisi. Yogyakarta: Kanisius, 1994.

Kuncoriningrat. Sejarah Kebudayaan Indonesia. Yogyakarta: Jambatan, 1954.

Munir, M Dan Wahyu Ilahi. Manajemen Dakwah dengan Kata Pengantar Oleh Yunan Yusuf dan Ketua Program Studi Dakwah dan Komunikasi Pascasarjana Uin. Jakarta: Rahmat Semesta dan Kencana, 2006.

Muliadi. Dakwah Inklusif. Makassar: Alauddin University Press, 2013.

Mahmuddin, Manajemen Dasar/Proses, Model, Pelatihan dan Penerapannya. Alauddin: University Press, 2001.

Malaikah, Mustafa. Manhaj Dakwah Yusuf Al-Qur'an Harmoni Antara Kelembutan dan Ketegasan. Jakarta: Pustaka Al-Kautsar, 1997.

Moeleong, Lexy J. Metode Penelitian Kualitatif. Bandung: Remaja Kerta Karya, 1998.

M.Z., K.H. Zainuddin. Figur Da'i Berjuta Umat.Cet I: Surabaya: Penerbit Kurnia, 1995.

Mubarok, Zacky. "Dakwah KH Mohammad Cholil Bisri dalam Bidang Politik" Skripsi. Semarang: Fakultas Dakwah Iain Walisongo Semarang, 2011.

Nata, Abuddin. Metodologi Studi Islam.Cet V; Raja Grafindo Persada, 2000. Poernomo,

Said, Muhammad Nurhidayat. Dakwah dan Efek Globalisasi Informasi.Makassar: Alauddin University Press, 2011. 
Agus Ahmad. Dasar-Dasar Tradisi. Jakarta: Bumi Aksara, 1993.

Tanjung, Didin Hafidhuddin Hendri. Manajemen Syariah dalam Praktik. Jakarta: Gema Insani Press, 2002. 